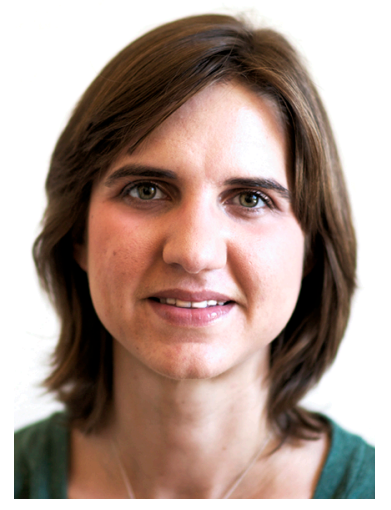

ELISE ERB is pursuing her bachelor's degree in History at Cal Poly, San Luis Obispo with a minor in Art History. Her historical interests lie in post-World War Two western political and social history. Most recently, she spent four months living in Washington, DC interning with the Trust for the National Mall. When she's not studying history, she can be found telling prospective students and alumni how awesome Cal Poly is, in her role as a College of Liberal Arts Ambassador. 


\title{
HANGING PROSPERITY ON A WALL: PRIVATE ART COLLECTING AS CONSPICUOUS CONSUMPTION, UNITED STATES, 1945-1960
}

\author{
Elise Erb
}

On a brisk evening in New York in the spring of 1949, cars pulled up on 57th Street. Out of the cars stepped well-dressed women, and well-educated men, each met by attendants in striped trousers. ${ }^{1}$ These members of high society stepped out not in front of a theatre or the latest restaurant; instead, they arrived at an art auction at Parke-Burnet galleries during the boom period of the American art market after the Second World War. Such patrons brought Parke-Burnet Galleries their most lucrative season ever in 1945, grossing more than six million dollars; the same spring that saw the end of the Second World War in Europe, bringing massive social and political changes to the world. ${ }^{2}$

The art market provides the perfect way to study American society as a whole in the time period of 1945 to 1960 . Scholars have examined all of the pieces that played into the art market after the Second World War: the general post-war climate, the economic trends in art collecting, and the theft of art during the war. ${ }^{3}$ All of these topics have been studied without intersecting

${ }^{1}$ Aline B. Louchheim, "Where Art and Economics Meet," New York Times, March 13, 1949.

2 "Art Auction Sales at Record High," New York Times, June 24, 1945. 
the three. The years from 1945-1960 encompassed a period when the average American lived in fear of "the bomb" and communism, watched jobs disappear as soldiers returned from the war, and traveled across the country on Route 66, the ultimate American road-trip. ${ }^{4}$ However, elite Americans found themselves with more disposable income than ever; income which they spent on art. ${ }^{5}$ Scholars have often examined art collecting as a broad topic from an economic standpoint, ignoring the life that art takes on as a social phenomena and an indicator of status. This view overlooks the human desire involved in the acquisition of a piece of art. Scholars such as William Goetzmann and W. G. Constable acknowledged that as the wealth of collectors increases so does the demand for art, but none took the step to explore the logic and social ramifications behind art collecting. ${ }^{6}$ Another topic of recent interest to scholars is the tragedy of Nazi and Soviet art theft. We know that the United States government established the elite military division of Reparations, Deliveries and Restitution dedicated to the return of looted works, but we do not know what the art elite in the states might have felt about these exploited works. ${ }^{7}$ The idea that the American social elite might have valued the unique history of a recovered piece of art is one that deserves further study. I argue that conspicuous consumption

\footnotetext{
${ }^{3}$ Works such as: Russell Bertrand, Détente or Destruction, 1955-1957 (London: Routledge, 2005); Michael Scheibach, Atomic Narrative and American Youth: Coming of Age with the Atom, 1945-1955 (Jefferson, NC: McFarland \& Co., 2003); Michael D. Pearlman, Truman and MacArthur: Policy, Politics, and the Hunger for Honor and Renown (Bloomington: Indiana University Press, 2008); Larry W. Blomstedt, "The Forgotten Attempts to End the Forgotten War: Congress, Korea, and McCarthyism," The Historian 72, no. 4 (Winter 2010): 781; Ted Morgan, Reds: McCarthyism in Twentieth Century America (New York: Random House, 2003); Louis Uchitelle, The Disposable American: Layofss and their Consequences (New York: Knopf, 2006); Francis H. Heller, ed., Economics and the Truman Administration (Lawrence: Regents Press of Kansas, 1981); Matthew B. Anderson, "The Discursive Regime of the 'American Dream' and the New Suburban Frontier: The Case of Kendall County, Illinois," Urban Geography 31, no. 8 (November 2010): 1080-1099.; Mickey Lauria, ed., Reconstructing Urban Regime: Regulating Urban Politics in the Global Economy, (Thousand Oaks: Sage, 1997).

${ }^{4}$ Marty Jeezer, The Dark Ages: Life in the United States, 1945-1960 (Boston: South End Press, 1982), 83.

${ }^{5}$ Ibid., 119.

${ }^{6} \mathrm{~W}$. G. Constable, Art Collecting in the United States of America (London: Thomas Nelson and Sons Ltd, 1964): v; William N. Goetzmann, "Accounting for Taste: Art and the Financial Markets Over Three Centuries," The American Economic Review 83 (December 1993): 1375.

${ }^{7}$ Lynn H. Nicholas, The Rape of Europa: The Fate of Europe's Treasures in the Third Reich and the Second World War (New York: Knopf, 1994): 325.
} 
became critical in post-war America in order for elites to show that they had not only survived the war, but were in fact now more prosperous than ever before.

\section{Conspicuous Consumption: Applying Veblen to the Post-war Art Market}

Private art collecting typically serves as a prime example of conspicuous consumption. Thorstein Veblen first presented the idea of conspicuous consumption in 1902 through his work The Theory of the Leisure Class. At its most basic, the concept suggests that society valued the consumption of goods for unproductive means because it became a mark of social status, especially the consumption of desirable goods. ${ }^{8}$ Veblen applied his ideas to servants, food, lifestyle and household goods in the early Victorian period in which he wrote.

In his writing, Veblen never specifically mentions the application of his ideas to art collecting among the social elite as a display of wealth, but I believe it to be a logical application of Veblen's ideas that has heretofore been unexplored. Veblen believed that conspicuous consumption could only be practiced in a "quasi-peaceable" time, which the United States achieved for the fist time in more than a decade during the post-war period. ${ }^{9}$ Collecting art took both time and money, things not squandered in times of turmoil. It took time to go to galleries and seek out pieces for purchase and viewing in New York. ${ }^{10}$ Americans did not experience art on a public and daily basis like Europeans living in old cities filled with old masters did. ${ }^{11}$ Art collecting allowed conspicuous consumption of both time and large amounts of money, showing that the money did not need to be used for practical means.

A critical part to understanding conspicuous consumption depends on understanding Veblen's definition of waste. Veblen defines waste in his context as the expenditure of time or money that does not serve human life or well being in general, not a misuse of time or money, as we tend to define waste in modern daily conversation. ${ }^{12}$ Through this definition, Veblen recognized that conspicuous consumption serves a purpose and is not useless, as an outsider might perceive it. For a modern audience, it is key to remember Veblen's understanding of waste as we apply his ideas to private art collecting.

\footnotetext{
${ }^{8}$ Thorstein Veblen, "Conspicuous Consumption," The Theory of the Leisure Class (New York: Macmillan, 1902): 53.

${ }^{9}$ Ibid., 65.

${ }^{10}$ Aline B. Louchheim, "Art: Mecca and Marketplace," The New York Times, February 1, 1953.

${ }^{11}$ Ibid.

${ }^{12}$ Veblen, “Conspicuous Consumption," 73.
} 


\section{Conspicuous Use of Idle Time: The act of buying as a social spectacle}

In the post-war art world, the show of status and conspicuous consumption began the moment the buyer set foot in the establishment where they would later purchase a work of art. Large-scale art auctions and private buying sessions became the two primary ways to legally acquire art in the United States after the Second World War. Different social implications came with each method of buying art: one showed conspicuous consumption through presence, and the other through the implied prestige of the work purchased.

Art auctions served as major social events, on the same scale as theatre. In her 1953 New York Times article, "Where Art and Economics Meet," Aline Louchheim described the scene at Parke-Burnet Galleries, the largest auction house in New York at the time, during one particular auction. She described the sale as an "exciting spectacle" with women dressed in mink coats and men peering at art through magnifying glasses. ${ }^{13}$ Louchheim said that attendants wearing "striped trousers" met these high-class potential buyers when their fancy cars glided up outside. ${ }^{14}$ Such ostentation would have been impossible for the rest of the social elite and passers-by to ignore.By showing up at the auction dressed in their finery, high society members gained status among their peers. In this case, it became more a matter of being seen than what they actually bought or did at the auction. Veblen addressed the idea that mere presence could serve as conspicuous consumption when he said that one's presence at an event served as a way to show strangers that one possessed social status. ${ }^{15}$ The social buying practices of the American elite in the post-war period perfectly evidence this idea. A socialite certainly did not purchase pieces at every auction attended, but every event they attended added to their social prestige and status.

Private buying provided an experience on the other end of the art-buying spectrum from art auctions. Dealers like Wildenstein \& Co. made their name selling only the finest and most desirable pieces of art. One news article, printed

\footnotetext{
${ }^{8}$ Thorstein Veblen, "Conspicuous Consumption," The Theory of the Leisure Class (New York: Macmillan, 1902): 53.

${ }^{9}$ Ibid., 65.

${ }^{10}$ Aline B. Louchheim, "Art: Mecca and Marketplace," The New York Times, February 1, 1953.

${ }^{11}$ Ibid.

${ }^{13}$ Louchheim, "Where Art and Economics Meet."

${ }^{14}$ Ibid.

${ }^{15}$ Veblen, "Conspicuous Consumption," 65.
} 
to celebrate the fiftieth anniversary of the firm, called Wildenstein \& Co. the "Cartier of the art world," a true testament to the caliber and prestige of the firm. ${ }^{16}$ When buying art from a dealer like this, the buyer would be ushered into a room covered in rich drapery with two chairs in the middle. The dealer would then bring paintings into the room to be shown one at a time, no more than six in a session. ${ }^{17}$ Only those who could afford the best and rarest of works could participate in the private buying experience.

While it may not seem that private buying would be conducive to displaying wealth publicly, this method brought status to the buyer through the prestige of the acquisition. The amount of money that Wildenstein \& Co. brought in allowed them to build up an impressive stock that included works by the likes of Rembrandt and Winslow Homer. The firm could then take their time selling the pieces for the best price and to the most prestigious buyer. ${ }^{18}$ Aline Louchheim explained the company's sales strategy: "Many of the greatest objects have been in the firm for twenty-five or thirty years. Many are rarely offered." ${ }^{19}$ This meant that while buying a piece from private sessions did not provide a public venue to display wealth, more prestige came from the act of owning a piece from one of these elite institutions. Visiting one of these institutions alone did not act as conspicuous consumption, but walking out having purchased something there certainly did.

The act of going to a public auction to purchase art was the most conspicuous act of the art acquisition process because it made the act of buying art public. Just as Veblen said that conspicuous waste of time should become an integral part of conspicuous consumption, going to art sales became a social expectation in order to maintain status. ${ }^{20}$ Whether purchased at an auction as part of a grand spectacle, or purchased in the privacy of a private buying room, the process of buying a work of art became a way of practicing conspicuous consumption. The pageantry of an auction and the prestige of owning a rare work of art showed status and wealth.

\footnotetext{
${ }^{16}$ Aline B. Louchheim, "A Half-Century of Dealing in Art," New York Times, November 11, 1951.

${ }^{17}$ Ibid.

${ }^{18}$ Ibid.

${ }^{19}$ Ibid.

${ }^{20}$ Veblen, “Conspicuous Consumption." 62.
} 


\section{Conspicuous Use of Idle Money: Owning as a social spectacle}

The conspicuous consumption did not end with the purchase of a piece of art. Just owning a piece of art did not automatically confer status upon the owner. Different attributes of the piece created different levels of conspicuous consumption. In his book Art as an Investment, Richard Rush explained that the determining factors in a painting's price in America in the post-war period were the following: artist and period of work, quality compared to other works by the artist, subject and size of the work, condition, previous ownership history, signature, who had owned the painting previously, seller, location, and timing of the sale, and who attended the sale. ${ }^{21}$

Aline Louchheim noted in 1949 that nineteenth-century French artists were the most desirable and most popular, along with newer realist and anecdotal paintings. ${ }^{22}$ Works by these artists sold for the most money on a regular basis. Owning one of these paintings would act as conspicuous consumption because other collectors knew that these works were of high value, and therefore had spent a significant amount of idle money to acquire the piece. Of course, the more rare the piece, the more money it took to purchase. Private dealers such as Wildenstien and Co. often sold pieces like this, meaning that prices came to be known only through anecdotal evidence. ${ }^{23}$

In 1961, approximately 500 people in the world were buying the highest priced works of art, those over 50,000 dollars. ${ }^{24}$ Not everyone buying in the United States at this time would have been in this elite category of buyers. However, the art buying public would have known which artists and styles were selling for the highest prices, so displaying certain works would display higher status.

The previous ownership and story of a piece also conferred value upon a painting. Ownership was important because if a painting had a well-known owner in the past, it had probably undergone examination for authenticity. The greater the number of previous owners, the better a reputation the painting had. ${ }^{25}$ Paintings with documents proving its authenticity, origin, and past,

\footnotetext{
${ }^{21}$ Richard H. Rush, Art as an Investment (Englewood Cliffs, New Jersey: Prentice-Hall, 1961): 290.

${ }^{22}$ Louchheim, "Where Art and Economics Meet," “Degas Work Brings \$25,000," New York Times, December 12, 1948.

${ }^{23}$ Louchheim, "A Half-Century of Dealing in Art," and "Where Art and Economics Meet."

24 Rush, Art as an Investment, 352.

${ }^{25}$ Ibid., 286.
} 
brought even more value to the piece. ${ }^{26}$ Previous ownership would also give a price history to the work, showing the new owner if the work gained or lost value and popularity. ${ }^{27}$

While previous ownership was an important part of the history of a work of art, the more recent history of art tragedy proved more exciting to buyers in this post-war period. Buyers in the years directly following the war were suddenly looking at pieces that had the unique history of being victims of Nazi and Soviet art theft during the war. The public knew what had happened because the major newspapers at the time ran stories about Nazi and Soviet atrocities during the war. ${ }^{28}$ The Nazis and Soviets began looting the nations that they invaded in the autumn of 1942, even going as far as creating specially trained art theft battalions. While pillaging occurred wherever the Nazis went, the majority of art raids took place in the private collections and museums of Europe. ${ }^{29}$ One writer for the Los Angeles Times, stationed in Paris at the time, wrote about watching as the French government moved the Mona Lisa out of the Louvre to protect it from Nazi looting. The pieces that were stolen either became part of the private collections of high-ranking Nazi leaders, or were tragically burned. ${ }^{30}$

As the Second World War drew to a close, the Allied forces created a task force commonly called the Monument Men, who retrieved as many of the looted pieces as they could. ${ }^{31}$ While this history is never specifically mentioned as a reason why the value of a piece would rise, this attribute is mentioned by Louchheim in her article "Where Art and Economics Meet" when discussing the pieces in a specific sale in $1949 .{ }^{32}$ This suggests that the tragic and exciting history of a piece would increase its value for the consumer of the day.

Because of the new history of the Second World War, this post-war period gave rise to new ideas as to what made a work of art valuable. Walter Benjamin was one of the thinkers who brought forth new ideas in this period. Benjamin posed the idea that works of art with unique histories would garner more money

\footnotetext{
${ }^{26}$ Russell Lynes, “The Taste Makers," Harper's Magazine, June 1947, 486.

${ }^{27}$ Ibid., 288.

${ }^{28}$ Eugene Tillinger, "History's Greatest Art Theft," Los Angeles Times, June 6, 1943.

${ }^{29}$ Nicholas, The Rape of Europa, 72, 15.

${ }^{30}$ Tillinger, "History's Greatest Art Theft."

${ }^{31}$ Nicholas, The Rape of Europa, 415.

${ }^{32}$ Louchheim, "Where Art and Economics Meet."
} 
on the market. In "The Work of Art in the Age of Mechanical Reproduction," Benjamin said that the "unique existence of the work of art determined the history to which it was subject to throughout the time of its existence." ${ }^{33}$ This meant that the work of art gained value and authenticity as time passed and it became a part of the fabric of history. In the context of private art collecting, this meant that pieces with a unique history could raise the potential for conspicuous consumption more than a work without a significant history.

Price necessarily served as the final indicator of conspicuous consumption in the art world. During the 1944-1945 season, the New York art market made its largest amount of money to that date, more than six million dollars. ${ }^{34}$ The post-war period was a time of economic boom, so the elite had much more money to invest into the purchase of art. ${ }^{35}$ This desire to purchase art created a bull market in the art world. ${ }^{36}$ This meant that the art market was selling more lucratively than in recent historical memory. Some scholars suggested that part of this desire for luxury items was fueled by Hollywood movies such as Gilda starring Rita Hayworth. Now Americans had the money to buy the luxuries highlighted in films for the first time in over fifteen years. ${ }^{37}$ Since no one had the money to buy luxury items during the war, purchasing art became a successful manner of conspicuous consumption because it created that Hollywood look for the first time since the war ended. This explains why a bull market in art occurred right after the war, the social elite wanted their due again having temporarily lost their wealth with the crash of the stock market and the entry of the United States into the war. ${ }^{38}$

The sheer act of spending money on a piece of art served as means of conspicuous consumption. However, for the piece to obtain status, it needed to have certain qualities of style, artist, price, and history. Americans showed

${ }^{33}$ Walter Benjamin. Illuminations, ed. H. Arendt and trans. H. Zohn, (London: Fontana: 1992 (orig. 1936)), 98.

${ }^{34}$ Two articles differ on the exact amount in sales during this season. The figure is quoted as $\$ 6,165,920$ in "Art Auction Sales at Record High." and as $\$ 6,604,045$ in Aline B. Louchheim, "Where Art and Economics Meet."

${ }^{35}$ Rush, Art as an Investment, 215.

${ }^{36}$ Goetzmann, "Accounting for Taste: Art and the Financial Markets Over Three Centuries," 1373.

${ }^{37}$ Jeezer, The Dark Ages: Life in the United States, 1945-1960, 118.

${ }^{38}$ Ibid., 34. 
their newly reacquired wealth by spending on the luxury items they gave up during the preceding depression and war, including art. ${ }^{39}$

\section{Making Conspicuous Consumption Conspicuous: Advertising the spectacle.}

The social elite of the post-war period went through the process of going to sales and buying art, but what good did this process serve it if no one knew about their purchases? Conspicuous consumption was about being seen. To ensure visibility, the social elite used the art sections of newspapers to advertise their newly acquired wealth to both those within and outside of, their social circles.

The primary way of advertising the procurement of art was through news "blurbs." Both before and after the sale, newspapers would run a story, often no more than a few lines, about the auction. The articles after the auctions summed up what had been bought, how much it cost, and when the buyer or seller allowed disclosure, who bought it. ${ }^{40}$ Articles printed before the sale would tell the reader the previous ownership of the works being sold, and highlight any important pieces. ${ }^{41}$ When the art auctions were in the paper before the actual sale occurred, it added status to the sale, and to the pieces bought there. One 1947 article detailed all of the works that would be sold at auction that weekend from the estate of Mrs. Walter B. James of New York. ${ }^{42}$ The pre-advertisement of a sale ensured a large turnout including the most elite members of art collecting society, which drove up the prices of the works and increased prestige. ${ }^{43}$ Articles that ran after the sale made sure that all members of society knew what had been bought by whom and for how much. Since not all of high society would be at any auction, high profile purchases were advertised so that wealth and social standing could be displayed for all to see. The short advertisements in newspapers provided just such an opportunity for

\footnotetext{
${ }^{39}$ Goetzmann, "Accounting for Taste: Art and the Financial Markets Over Three Centuries," 1373.

40 “\$45,720 Art Sale,” New York Times, February 27, 1947; “Painting Brings \$5,700,” New York Times, December 15, 1949; "Degas Work Brings \$25,000 at Auction," New York Times, December 12, 1948; “Art Works Bring \$50,970," New York Times, March 12, 1948; “Auction Yields \$87,945," New York Times, December 14, 1947; "Tapestry Brings \$1,900," New York Times, November 9, 1947; "Painting Sold for \$4,000," New York Times, March 12, 1946; “Jade Vase Brings \$1,700," New York Times, April 20, 1947.

41 "Rembrandt Works on Sale Tomorrow," New York Times, March 16, 1947.

${ }^{42}$ Ibid.

${ }^{43}$ Rush, Art as an Investment, 289.
} 
those who were not in attendance to see what was bought. This advertisement of what was bought allowed the vicarious consumption of the non-elites who could not participate in the art market because of the restrictive cost involved.

The "Arts" sections of major metropolitan newspapers provided another way of advertising wealth. These sections were not necessarily written for the elites already purchasing art. A critical reading Louchheim's article "Where Art and Economics Meet," reveals that everyday newspaper readers were likely the intended audience, not the art collecting elite. The article gives an in-depth description of what an art auction was like and what went into each auction. ${ }^{44}$ The art buying elite would not have need to be told what happened at an art sale because they would have known from experience, however, the general public would have held a high interest into what happened at an art auction. After years of economic turmoil, the American people needed a way to prove that the worst was over and they were once again on top of the global market. ${ }^{45}$ The social practices of the rich, art buying elite provided the perfect way to see proof of the return of good times.

In order for this to be clear in the packed metropolises of post-war America, conspicuous consumption needed advertisement. Veblen recognized this and said that wealth could not be properly advertised unaided. ${ }^{46}$ In other words, Veblen meant that wealth would not advertise itself. Conspicuous consumption of art meant making sure that all members of society knew about the acquisition of art. The newspapers were the best way to achieve this advertisement in the post-war world.

\section{Conspicuous Consumption: Showing America that better days were here again}

In the post-war period in America, the art world became an outlet for social elites to practice conspicuous consumption. From the moment society members stepped out of their shiny black cars in front of an auction house, they proved that they had achieved prosperity once again. Even those who bought their art in the confines of private buying rooms showed their wealth through the prestige attached to their purchases. The art itself gained or lost prestige based

\footnotetext{
${ }^{44}$ Louchheim, "Where Art and Economics Meet."

${ }^{45}$ Jeezer, The Dark Ages: Life in the United States, 1945-1960, 120.

${ }^{46}$ Veblen, "Conspicuous Consumption," 57.
} 
on various attributes of the painting including artist, price, and previous history. In this post-war period, previous history came to include the history of Nazi and Soviet art theft during the Second World War. Art collection would have gone largely unnoticed if newspapers had not published stories about the art market, and specific art sales, for art collecting elites and everyday people alike.

The act of conspicuous consumption became important in the post-war era because the elites needed to show they survived the sixteen-year period of war and economic depression that just ended. The social elite needed a way to prove they more than just survived, but came out as affluent as before, if not more. This may have seemed like a waste of time and money, but it proved they did not need that time to work, or that money to buy necessities: a luxury that had not existed just a few years before. Art became more than just something to hang on a wall. It became a way to demonstrate status in a world where status could once again be relevant, perhaps even reveled in, and not be seen as distasteful. 
“\$45, 720 Art Sale.” New York Times, February 27, 1947.

“Art Auction Sales at Record High.” New York Times, June 24, 1945.

“Art Works Bring \$50, 970.” New York Times, March 12, 1948.

“Auction Yields \$87, 945.” New York Times, December 14, 1947.

Benjamin, Walter. Illuminations. (original 1936) Edited by H. Arendt and translated by H. Zohn. London: Fontana, 1992.

Constable, W.G. Art Collecting in the United States of America: An Outline of a History. London: Thomas Nelson and Sons, 1964.

“Degas Work Brings \$25,000 at Auction.” New York Times, December 12, 1948.

Goetzmann, William N. "Accounting for Taste: Art and the Financial Markets Over Three Centuries.” The American Economic Review 83, no. 5 (December 1993): 1370-1376.

“Jade vase Brings \$1,700.” New York Times, April 20, 1947.

Jezer, Marty. The Dark Ages: Life in the United States, 1945-1960.Boston: South End Press, 1982.

Louchheim, Aline B. “Art: Mecca and Marketplace.” New York Times, February 1, 1953.

_. "A Half-Century of Dealing in Art." New York Times, November 11, 1951.

_. "Where Art and Economics Meet." New York Times, March 13, 1949.

Lynes, Russell. “The Taste Makers.” Harper's, June 1947, 481-491.

Nicholas, Lynn H. The Rape of Europa: The Fate of Europe's Treasures in the Third Reich and the Second World War. New York: Alfred A. Knopf, 1994.

“Painting Brings \$5,700 at Auction.” New York Times, December 15, 1949.

“Painting Sold for \$4,000.” New York Times, March 12, 1946. 
Rush, Richard H. Art as an Investment. Englewood Cliffs, New Jersey: Prentice Hall, 1961.

“Tapestry Brings \$1,900.” New York Times, November 9, 1947.

Tillinger, Eugene. “History's Greatest Art Theft.” Los Angeles Times, June 6, 1943.

Veblen, Thorstein. "Conspicuous Consumption." In The Theory of the Leisure Class, 53-75. New York: Macmillan, 1902.

\section{WORKS CONSULTED}

Anderson, Matthew B. “The Discursive Regime of the 'American Dream' and the New Suburban Frontier: The Case of Kendall County, Illinois.” Urban Geography 31, no.8 (November 2010): 1080-1099.

Bertrand, Russell. Détente or Destruction. London: Routledge, 2005.

Blomstedt, Larry W. "The Forgotten Attempts to End the Forgotten War: Congress, Korea, and McCartyism." The Historian 72, no.4 (Winter 2010): 781.

Heller, Francis H., ed. Economics and the Truman Administration. Lawrence: Regents Press of Kansas, 1981.

Lauria, Mickey, ed. Reconstructing Urban Regime: Regulating Urban Politics in the Global Economy. Thousand Oaks: Sage, 1997.

Morgan, Ted. Reds: McCarthyism in Twentieth Century America. New York: Random House, 2003.

Pearlman, Michael D. Truman and MacArthur: Policy, Politics, and the Hunger for Honor and Renown. Bloomington: Indiana University Press, 2008.

Scheibach, Michael. Atomic Narratives and American Youth: Coming of Age with the Atom, 1945-1955. Jefferson: McFarland \& Co., 2003.

Uchitelle, Louis. The Disposable American: Layoffs and their Consequences. New York: Knopf, 2006. 